\title{
Valuation of Country Food in Nunavut Based on Energy and Protein Replacement
}

\author{
Duncan W. Warltier, ${ }^{1,2}$ Manuelle Landry-Cuerrier ${ }^{1}$ and Murray M. Humphries ${ }^{1}$
}

(Received 16 June 2020; accepted in revised form 29 January 2021)

\begin{abstract}
Communicating value across the pluralities of Indigenous Peoples' food systems requires attention to economy and environment, food and wildlife, and the health of the people and that of the land. Valuation of distinct entities is always difficult but often essential to describe collective wealth and well-being, to quantify trade-offs, and to consider compensation when one is compromised for another. Here we estimate the replacement value of Nunavut country food by combining information on the amount and nutritional composition of harvested country food with the nutritional content and local price of store-bought food. Comparing the five-year average of energy and protein available in reported harvest to recommended dietary allowances indicates that 17 of 21 Nunavut communities harvest enough country food to satisfy the protein requirements of all community members. Nunavut's country food system annually harvests five million $\mathrm{kg}$ of protein-rich food from across the territory, which would cost $\$ 198$ million to purchase as store-bought protein, with a replacement value between $\$ 13.19$ and $\$ 39.67$ per kg depending on energy versus protein replacement and the inclusion versus exclusion of store-bought food subsidies. These valuations are higher than most previous estimates of local food value because they are more reflective of the energy and nutrient richness of country food and the high price of store-bought food in northern communities. The country food system is priceless in many, profound ways; better awareness of its energy and protein cost of replacement, together with the breadth of its nutritional and cultural value, may help to ensure local food systems are prioritized in northern food security and economic development initiatives.
\end{abstract}

Key words: subsistence; traditional food; mixed economies; wildlife; hunting; nutrition; Arctic; food policy; Inuit, Nunavut

RÉSUMÉ. La communication de la valeur à travers les pluralités des systèmes alimentaires des peuples autochtones doit tenir compte de l'économie et de l'environnement, de l'alimentation et de la faune, de la santé des gens et de celle de la terre. L'évaluation d'entités distinctes est toujours difficile, mais souvent essentielle pour décrire la richesse et le bien-être collectifs, pour quantifier les concessions et pour considérer une compensation lorsqu'un système est compromis en raison d'un autre. Dans cet article, nous estimons la valeur de remplacement de la nourriture traditionnelle du Nunavut en combinant des données sur la quantité et la composition nutritionnelle des aliments récoltés sur le terroir, ainsi que sur le contenu nutritionnel et le prix local de la nourriture achetée en magasin. La comparaison de la moyenne quinquennale des données en valeur énergétique et protéique provenant des récoltes déclarées aux apports nutritionnels recommandés permet de constater que 17 des 21 collectivités du Nunavut récoltent suffisamment de nourriture traditionnelle pour satisfaire aux besoins en protéines de tous les membres des collectivités. Annuellement, le système alimentaire traditionnel du Nunavut donne lieu à des récoltes de cinq millions de kilogrammes de nourriture riche en protéines à l'échelle du territoire, ce qui représenterait des achats d'aliments protéinés en magasin d'une valeur de 198 millions de dollars, moyennant une valeur de remplacement s'échelonnant entre 13,19 \$ et 39,67 \$ le kilogramme, selon que le remplacement est calculé en fonction de la valeur énergétique ou protéique, et avec inclusion ou exclusion des subventions au titre de la nourriture achetée en magasin. Ces évaluations sont plus élevées que la plupart des estimations antérieures de la valeur de la nourriture locale parce qu'elles tiennent davantage compte de la valeur énergétique et de la richesse en nutriments de la nourriture traditionnelle ainsi que du prix élevé de la nourriture achetée en magasin dans les collectivités nordiques. À bien des égards importants, le système alimentaire traditionnel a une valeur inestimable. Le fait de prendre davantage conscience du coût de remplacement de la valeur énergétique et protéique des aliments, en plus de l'ampleur de la valeur culturelle et nutritionnelle du système, pourrait aider à faire en sorte que les systèmes alimentaires locaux soient priorisés par les initiatives de sécurité alimentaire et de développement économique dans le Nord.

Mots clés : subsistance; nourriture traditionnelle; économies mixtes; faune; chasse; nutrition; Arctique; politique alimentaire; Inuit, Nunavut

Traduit pour la revue Arctic par Nicole Giguère.

\footnotetext{
${ }^{1}$ Centre for Indigenous Peoples' Nutrition and Environment, Macdonald Campus, McGill University, 21111 Lakeshore Road, Ste-Anne-de-Bellevue, Québec H9X 3V9, Canada

${ }^{2}$ Corresponding author: duncan.warltier@mail.mcgill.ca

(C) The Arctic Institute of North America
} 


\section{INTRODUCTION}

The lifeways of Indigenous Peoples and northern regions connect economy and environment (Kuokkanen, 2011), food and wildlife (Kuhnlein and Humphries, 2017), and the health of the people to the health of the land (Dudley et al., 2015). Communicating value and status across these pluralities is always difficult because they are segregated in contemporary governance, policy, and assessment (Lysenko and Schott, 2019) but is often essential to describe collective wealth and well-being, to quantify trade-offs, and to consider compensation when one system is compromised for another. Nevertheless, cross-system valuations are contested and controversial. For example, ecosystem services approaches (especially payments for ecosystem services) are frequently criticized as a commodification of nature through which dominant political and economic views are allowed to define how we conceive of, communicate, and compensate for the value of biodiversity and nature (Gómez-Baggethun and Ruiz-Pérez, 2011).

Kosoy and Corbera (2010) refer to this problem as commodity fetishism, arguing that monetary valuation of any biocultural system obliterates the social, cultural, and ecological qualities embedded in these systems, thereby failing to account for value in a broader sense. But despite their anthropocentric framing, an ecosystem services approach and natural capital accounting are also promoted as an argument for protection of nature, as means to support conservation and sustainable use, and as boundary concepts capable of connecting and distinguishing diverse perspectives and values (Abson et al., 2014; Schröter et al., 2014).

The food systems and food security of northern and Indigenous Peoples are social-ecological phenomena situated at the intersection of economy and environment, food and wildlife, and biocultural well-being (Kuhnlein et al., 2009). Country food (subsistence focused on the hunting, fishing, and gathering of local wild animals and plants; Searles, 2016) is a key contributor to the food security (Ford and Berrang-Ford, 2009), nutrient intake (Johnson-Down and Egeland, 2010; Kenny et al., 2018a), and the social economy in Inuit Nunangat (Natcher, 2009; Harder and Wenzel, 2012). However, country food consumption is being negatively impacted by the high costs of harvesting equipment (Wenzel, 2000; Lambden et al., 2007), changing food preferences (Kuhnlein and Receveur, 1996; Sheehy et al., 2013), and climate and land-use changes that are impacting wildlife and restricting access to harvesting areas (Chan et al., 2006; Wenzel, 2009).

Store-bought food is also a key contributor to nutrition and food security in northern and Arctic communities, and the high cost of store-bought food, combined with low incomes and limited access to wage economies, is a widely identified barrier to food security in Nunavut (Nunavut Food Security Coalition, 2014) and across northern regions (CCA, 2014). High rates of food insecurity across northern Canada have been attributed to a variety of factors including limited access, availability, and use of healthy country food or healthy store-bought food (CCA, 2014), especially in Nunavut, where food insecurity affects $50 \%$ to $80 \%$ of households, which is 10 times higher than the Canadian average (Wakegijig et al., 2013; Nunavut Food Security Coalition, 2014). The extent to which economy, environment, and culture co-determine food security is reflected in how the Nunavut Food Security Coalition (2014:2) describes the four components of food security in Nunavut: "availability (enough wildlife on the land or groceries in the store), accessibility (adequate money for hunting equipment or store-bought food, and the ability to obtain it), quality (healthy food that is culturally valued), and use (knowledge about how to obtain, store, prepare, and consume food)."

Economic development, food security, and climate change adaptation have emerged as key pillars of northern policy and investment. However, economic investment often focuses on job creation through natural resource exploration and extraction (e.g., Caine and Krogman, 2010; Rodon and Lévesque, 2015), food security investment in subsidy programs intended to reduce the cost of storebought food (Galloway, 2017; St-Germain et al., 2019), and climate adaptation in relation to transportation, infrastructure preparedness, and technology-assisted agrifood production (Prowse et al., 2009; Hjort et al., 2018; Sustainable Development Working Group, 2019). While these are important initiatives and investments that are helping to transform northern economies and communities, they can be argued to be peripheral and transient to the primary economy that has long defined and continues to define northern regions (Wenzel, 2017). The country food system is the food that feeds Nunavummiut (the people of Nunavut), the labour that employs Nunavummiut, the economy that supports Nunavummiut, and the culture that defines Nunavummiut (Nunavut Food Security Coalition, 2014; Quintal-Marineau, 2017; Ready, 2017; Wenzel, 2017).

Not surprisingly, local opposition to or approval for transportation and resource development initiatives most often depends on their impacts on wildlife populations, the environment, and the integrity of the country food system (Caine and Krogman, 2010; Rodon and Lévesque, 2015; Carter et al., 2019). As articulated by the Nunavut Food Security Coalition (2014:7), "preserving the ecological integrity of Nunavut food resources is a key component of a sustainable food system in Nunavut, and is therefore of concern to food security." Community-suggested improvements for the subsidy program emphasized the need to expand the program to address economic barriers to country food access (GC, 2017). Community-led research on climate change adaptation has shifted adaptation focus towards helping hunters to safely access harvest sites, community freezers for the safe storage of country food, and elder-to-youth knowledge transmission related to the land and country food harvest and its preparation (Furgal and Seguin, 2006; Ford et al., 2014; Champalle et al., 2015).

Although country food has long been recognized and communicated by Nunavummiut as a made-in-Nunavut 
sustainability and food security solution, it has been marginalized and, in some cases, compromised by economic, food policy, and adaptation initiatives often envisioned and sometimes implemented from outside the region. Marginalization of local food systems may reflect broader and more complex dynamics rooted in legacies of colonialism, dispossession, a Eurocentric worldview, and modern power asymmetries (Caine and Krogman, 2010; Burow et al., 2018; Bernauer, 2019). In this context, the failure to quantify and communicate the value of local food systems may both arise from and contribute to their marginalization; a positive feedback loop that causes the system to be undervalued and underappreciated except by those directly involved in the system. Any one study or analysis can only scratch the surface of communicating the nature, value, and complexities invoked by the governance of food systems and traditional lifeways (CCA, 2014).

Cognizant of these limitations and our own positionality as Euro-Canadian, university-based researchers, we proceed by proposing a hypothesis. If the lack of reproducible quantification and economic valuation of the Nunavut country food system has contributed to its discounting and marginalization in northern economic development and food security policy, and we can provide a reasonable valuation that communicates the magnitude and scope of its contributions, then future discussions and decisions related to Nunavut and northern economic development and food security will be better able to situate the value of country food in descriptions of collective wealth and well-being, quantify trade-offs, and contemplate compensation when one economy is compromised for another. Unfortunately, this hypothesis cannot be tested by the results presented here, but rather by how these results are interpreted and applied by others. For Nunavummiut, the results presented here may offer nothing new; all the evidence they need may already be provided by the stories they know to be true, by the experience of their family's harvests, and by the food in their freezers that they share with others and eat themselves. However, other readers and policy makers, who rely more on numbers and currencies to define value, will offer a more direct test of this hypothesis. We hope that the valuation methodologies described here might prove useful to community and regional organizations in communicating at least some of the value offered by their local food systems and in emphasizing the importance of considering this value in policy decisions related to Arctic lands, wildlife, and food systems.

Given local food systems are fundamentally priceless, communicating their monetary value requires equating them to a monetized commodity, while recognizing this equivalency is inevitably imperfect and incomplete. Because of the partial nature of this estimate and the irreplaceability of many culturally appropriate foods, it logically follows that it will form a highly conservative estimate - what could be considered a lower boundary for future elaborations. Past attempts at local food valuation have been based either on exchange value (the monetized value of a commodity for which local food is traded for or exchanged; e.g., Usher, 1971) or replacement value (money that must be spent to replace what local food provides; e.g., DeLury et al., 1975; Berkes et al., 1994; Pal et al., 2013). We adopt a replacement value approach, which reflects DeLury et al.'s (1975:238) recognition that food is a fundamental need that must be replaced and cannot be exchanged: "[Exchange] values may have some relevance to a commercial fishery but not to a subsistence fishery. If fish keep an individual from starvation or even hunger then the fish assume a unit of value not found in any monetary system. To obtain a meaningful value for the fish, the costs of substitutes might be applied." We also improve upon previous replacement valuations focused only on food weight (e.g., Berkes et al., 1994; Pal et al., 2013) by assessing the local, store-bought food cost of nutrient replacement, which also serves to situate country food value in a broader economic and nutritional context.

\section{METHODS}

Our country food valuation methodology combines harvest data from the Nunavut Wildlife Harvest Study (NWHS; Priest and Usher, 2004), nutrient composition of country food from the Canadian Nutrient Files (CNF; Health Canada, 2018), and the price and nutrient content of store-bought food included in Revised Northern Food Baskets (RNFB; Nutrition North Canada, 2018). Our analysis includes wildlife harvest data from 27 Nunavut communities (including 13 Qikiqtaaluk communities, seven Kitikmeot communities, and seven Kivalliq communities) and RNFB price data from 21 communities (Fig. 1). We situate the estimated value of country food within a broader socioeconomic context through comparisons to recommended dietary allowances (RDA; Health Canada, 2010), reported incomes, and estimated economic productivity by sector (GN, 2019). To standardize financial valuations made several decades apart, all dollar values have been converted into 2016 Canadian dollars, using the Bank of Canada Inflation calculator (Bank of Canada, 2019).

\section{Country Food Harvest and Nutrient Composition}

We base our analysis on the five-year NWHS (June 1996-May 2001, treated as the 1996-2000 harvesting seasons for this analysis), which was mandated by the Nunavut Lands Claim Agreement to determine current harvesting levels and patterns of Inuit use of wildlife resources and aid in the calculation of basic needs levels (Priest and Usher, 2004). Harvest data were collected monthly from Inuit hunters for a total of five years (except Cape Dorset and Iqaluit, which were limited to 1997-2000). For our present analyses, we obtained NWHS data from the Arctic Observation Network (AON) subsistence database (Kruse, 2011), maintained by the Institute of Social and Economic Research at the University of Alaska, Anchorage 


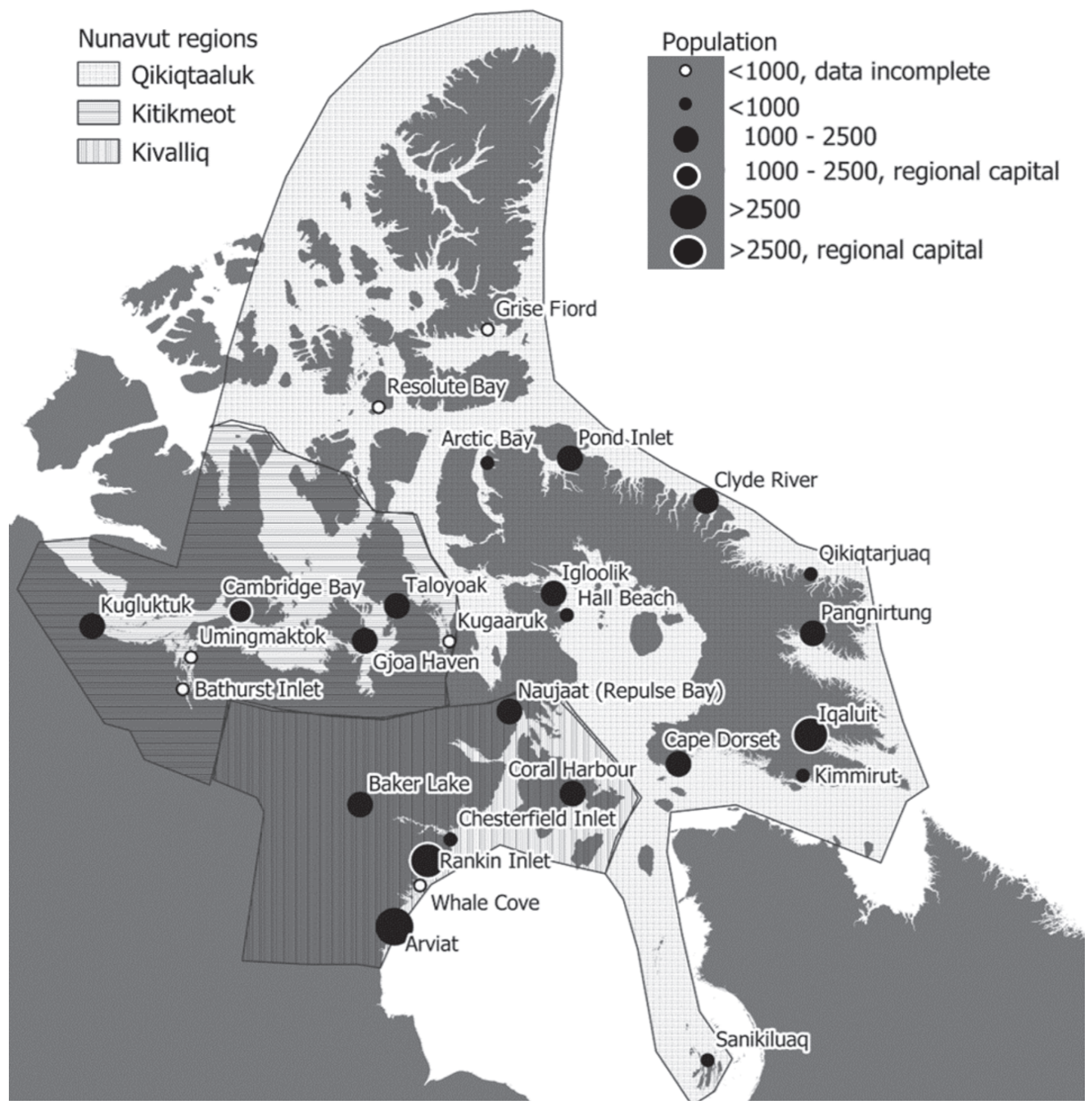

FIG. 1. Nunavut communities reporting country food harvest in the Nunavut Wildlife Harvest Study, with community symbols scaled to indicate population size (from the 2016 Canadian census). Patterned areas indicate Nunavut regions, and communities with white outlines are regional capitals (Rankin Inlet in Kivalliq and Cambridge Bay in Kitikmeot) and the territorial capital of Iqaluit. Six communities reporting harvest data but lacking store-bought food price data or censused inhabitants are indicated with white circles.

(Kruse, 2011). This database uses edible weights published by the Subsistence Division of the Alaska Department of Fish and Game (Conger and Magdanz, 1990; Titus et al., 2009; Magdanz et al., 2010) to convert whole animals harvested as reported in NWHS to kilograms of country food available to each community member $\left(\mathrm{kg}\right.$ person $\left.{ }^{-1}\right)$. Although the AON database includes harvest studies from other regions, our current analysis is restricted to results from the NWHS. We further limit our analysis to the 10 most harvested species in each community in each year, which encompass at least $97 \%$ of the total biomass harvested in each community in each year.

Harvest data were converted to available energy (kcal) and protein (g) (Tables S1, S2), using energy ( $\mathrm{kcal} \mathrm{kg}^{-1}$ ) 
and protein $\left(\mathrm{g} \mathrm{kg}^{-1}\right)$ contents reported in the CNF (Health Canada, 2018). Eider (Somateria mollissima) and Arctic hare (Lepus arcticus) nutritional data were obtained from Kuhnlein and Humphries (2017). The portion consumed was assumed to consist primarily of muscle for most wildlife species (Table S1), except for pinnipeds and cetaceans, which were constructed assuming preferential consumption of multiple tissues, including dried meat, maktaak/muktuq (skin), or misiraq (rendered oil; Table S2). Note that these assumptions are not equivalent to assuming all other parts were discarded. All parts routinely consumed are included in the edible yield $(\mathrm{kg})$ calculation from AON. The assumptions stated here and in Tables S1 and S2 relate only to estimating the average nutrient composition of the fraction consumed $\left(\mathrm{kcal} \mathrm{kg}^{-1}\right.$ or $\left.\mathrm{g} \mathrm{kg}^{-1}\right)$. Data for unspecified species or species without nutritional data were constructed using the average of their taxonomic group (Tables S1, S2).

\section{Country Food Available Energy and Protein in Relation to $R D A$}

The energy and protein available from reported country food harvests were estimated by multiplying the edible yield of harvested species by their species-specific nutrient composition, then summing across the top 10 harvested species to yield per capita estimates of country food available energy (kcal pers ${ }^{-1} \mathrm{~d}^{-1}$ ) and country food available protein $\left(\mathrm{g} \mathrm{pers}^{-1} \mathrm{~d}^{-1}\right)$. To assess the adequacy of country food harvest to meet nutritional requirements of the population, available energy and protein were compared to energy $\left(2300 \mathrm{kcal}^{\text {pers }}{ }^{-1} \mathrm{~d}^{-1}\right)$ and protein $\left(47 \mathrm{~g} \mathrm{pers}^{-1} \mathrm{~d}^{-1}\right)$ RDA, averaged across an adult male, adult female, teenage male, and pre-teen female (Health Canada, 2010), the same family-unit composition assumed by the RNFB. Relating country food available energy and protein estimated at a community level to an individual RDA implicitly assumes all foods harvested are consumed and harvested food is shared among community members proportional to their nutritional needs. These assumptions represent a simplification of the food system for analysis, which is a food system often characterized by highly unequal harvesting efforts (ranging from non-hunters to "super hunters", Chabot, 2003:19; Lysenko and Schott, 2019: Fig. 6) and within which country food accessibility that are partially but not fully equalized by food-sharing traditions (Ready and Power, 2018; Lysenko and Schott, 2019).

\section{RNFB Prices and Nutrient Content}

The cost of store-bought energy and protein in Nunavut was estimated from the price and nutrient content of a RNFB, designed to provide a week of food to a family unit of four, from reporting retailers in Nutrition North eligible communities in March 2016 (Nutrition North Canada, 2018). Given household crowding in Inuit Nunangat (RuizCastell et al., 2015), the assumption of four individuals per household will be in many cases incorrect. Because this assumption forms the basis of the RNFB estimation, we retain it but ensure it is made explicit by hereafter referring to a four-person household. The total energy content and total protein content of a RNFB were calculated based on the itemized content of a food basket, including serving mass or volume, adjusted by item density when necessary, and multiplied by CNF-reported energy and protein content (Revised Northern Food Basket, 2007; Health Canada, 2018). Energy and protein content were then divided by the community-specific price of the RNFB to arrive at a community-specific unit price for energy (store-bought food energy cost; $\$ \mathrm{kcal}^{-1}$ ) and protein (store-bought food basket protein cost; $\left.\$ \mathrm{~g}^{-1}\right)$.

Because store-bought food prices are subsidized in Nunavut by the Nutrition North program (in addition to other agricultural and food subsidies), we also estimated store-bought food basket energy and protein cost in the absence of the Nutrition North subsidy provided to eligible retailers in eligible communities. Nutrition North subsidies, calculated according to food item mass and category (higher, lower, no subsidy) and a communityassigned subsidy rate, were obtained via a data access request fulfilled by Nutrition North in February 2020. The unsubsidized RNFB cost was calculated as retail price plus the total subsidies applied to a RNFB in each community. The unsubsidized RNFB price was then divided by energy and protein content to estimate the unsubsidized storebought food energy cost $\left(\$ \mathrm{kcal}^{-1}\right)$ and unsubsidized storebought food protein cost $\left(\$ \mathrm{~g}^{-1}\right)$.

\section{Store-bought Food Affordability}

The affordability of store-bought food was estimated for four-person households located in different Nunavut communities by comparing a community-specific estimate of annual four-person household income to a communityspecific store-bought food price of 52 weekly RNFBs. Fourperson households were assumed to be supported by a single total income, which was assumed to equal the median total income reported by all tax filers in that community in 2016 (GN, 2019). Total income was chosen over employment income for this analysis, as it comprises labour income plus other sources including pensions, childcare benefits, and other government assistance and is therefore more reflective of the total financial resources available to a four-person household. Because the fraction of total income required to purchase basic food requirements is used as a measure of food poverty (Lee et al., 2013), we express annual RNFB food costs as a proportion of total annual income and refer to this community-specific measure as a store-bought food poverty index.

\section{Country Food Nutrient Replacement Value}

The nutrient replacement value of country food was estimated by multiplying the total energy $\left(\mathrm{kcal} \mathrm{yr}^{-1}\right)$ and protein harvested $\left(\mathrm{g} \mathrm{yr}^{-1}\right)$ by the local store-bought cost 
of energy $\left(\$ \mathrm{kcal}^{-1}\right)$ and protein $\left(\$ \mathrm{~g}^{-1}\right)$, including Nutrition North subsidized and unsubsidized costs. The average value of country food per unit mass $\left(\$ \mathrm{~kg}^{-1}\right)$ was calculated by dividing total harvest value $\left(\$ \mathrm{yr}^{-1}\right)$ by total harvest mass $\left(\mathrm{kg} \mathrm{yr}^{-1}\right)$.

\section{Comparison to Previous Country Food Valuations}

Several previous values presented in the literature were adjusted from the form in which they were originally published, including inflation adjustments and conversion of pounds to kilograms. Wenzel (2009) published a value of $\$ 35$ million for the annual country food harvest in Nunavut but did not reference a harvest level, so we assumed the NWHS edible yield harvest level of 3.4 million $\mathrm{kg}$, as estimated in our current analysis, and converted $\$ 35$ million $\mathrm{yr}^{-1}$ to $\$ 39.3$ million $\mathrm{yr}^{-1}$ to reflect 2016 dollars. Dividing $\$ 39.3$ million $\mathrm{yr}^{-1}$ by 3.4 million $\mathrm{kg} \mathrm{yr}^{-1}$ yields a value estimate of $\$ 11.56$ $\mathrm{kg}^{-1}$ from Wenzel (2009). O'Garra (2017) used a value of $\$ 6 \mathrm{USD} \mathrm{lb}^{-1}$ (from Fall, 2014), which we converted to $\$ 7.46$ CAD (assuming $\$ 1 \mathrm{CAD}=\$ 0.74 \mathrm{USD}$ ) and re-expressed per $\mathrm{kg}$, yielding a CAD value estimate of $\$ 17.81 \mathrm{~kg}^{-1}$. For Berkes et al. (1994), total replacement value $(\$ 7,846,155)$ was divided by total harvest $(686,713 \mathrm{~kg})$ to yield $\$ 11.43 \mathrm{~kg}^{-1}$ or $18.86 \mathrm{~kg}^{-1}$ in 2016 dollars. We also compare our valuations to a previous Government of Nunavut territory-wide estimate of country food value on its website (GN, 2021) without an explanation of methodology.

\section{Country Food System as an Economic Sector}

Country food values were compared to territorial economic sector gross domestic product (GDP) data (GN, 2019), organized by North American Industry Classification System (NAICS) codes (NAICS, 2017). The value of the oil and gas sector was estimated as the difference between the code 21 sector (Mining, quarrying, and oil and gas extraction) and its subsectors (2122: Metal ore mining and 2131: Support activities for mining and oil and gas extraction). The hunting, fishing, and trapping sector was defined by code 114 and intended to represent "establishments primarily engaged in catching fish and other wild animals from their natural habitats" (NAICS, 2017:99).

\section{Country Food Wealth Indices}

We are not aware of preexisting food affordability or food poverty indices that incorporate access to country foods, so we developed two measures. The first considers country food as a non-monetized commodity by relating country food harvest amounts to community nutritional requirements as outlined above (see Country Food Available Energy and Protein in Relation to RDA). We refer to this measure as a country food wealth nutrition index (CFWNI) and base it on nutrient amounts harvested per capita relative to recommended dietary allowances. Thus, for protein, this nutrition index is calculated as:

$$
\begin{aligned}
\mathrm{CFWNI}_{\text {protein }} & =\frac{\text { harvested protein }\left(\mathrm{g} \mathrm{person}^{-1} \mathrm{~d}^{-1}\right)}{\text { protein RDA }\left(\mathrm{g}_{\text {person }} \mathrm{d}^{-1}\right)} \\
& =\frac{\text { harvested protein }\left(\mathrm{g} \mathrm{person}^{-1} \mathrm{~d}^{-1}\right)}{47 \mathrm{~g}_{\text {person }} \mathrm{d}^{-1}}
\end{aligned}
$$

and for energy as:

$$
\begin{aligned}
& \mathrm{CFWNI}_{\text {energy }}=\frac{\text { harvested energy }\left(\mathrm{kcal}_{\text {person }}^{-1} \mathrm{~d}^{-1}\right)}{\text { energy RDA }\left(\text { kcal person }^{-1} \mathrm{~d}^{-1}\right)}
\end{aligned}
$$

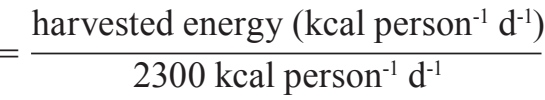

The second index we developed acknowledges the reality and the importance of the mixed economy in Nunavut communities by comparing the value of harvested country food to reported incomes. This country food wealth income index (CFWII) is calculated for protein value as:

$$
\mathrm{CFWII}_{\text {protein }}=\frac{\text { harvested protein value }\left(\$ \text { person }^{-1} \text { year }^{-1}\right)}{\text { reported income }\left(\$ \text { year }^{-1}\right)}
$$

and for energy value as:

$$
\mathrm{CFWII}_{\text {energy }}=\frac{\text { harvested energy value }\left(\$ \text { year }^{-1}\right)}{\text { reported income }\left(\$ \text { year }^{-1}\right)}
$$

\section{RESULTS}

The NWHS included 39 harvested species, species groups, or items (e.g., eggs), with estimated edible yield protein content ranging from 88 to $348 \mathrm{~g} \mathrm{~kg}^{-1}$ and energy content ranging from 820 to $5934 \mathrm{kcal} \mathrm{kg}^{-1}$ (Fig. 2a, b). Most Nunavut communities harvested edible yields exceeding $5 \mathrm{~kg}$ person ${ }^{-1}$ year $^{-1}$ across four or more species categories (Fig. 2c), with caribou (median $68.5 \mathrm{~kg}$ person $^{-1}$ year $^{-1}$, range $0.369-757 \mathrm{~kg}$ person $^{-1}$ year $\left.^{-1}\right)$, ringed seal $(28.6,0.192-270$ kg person $^{-1}$ year $\left.^{-1}\right)$, and char $\left(12.0,0.159-101 \mathrm{~kg}\right.$ person $^{-1}$ year $\left.^{-1}\right)$ as the three most harvested categories. In general, fish have lower protein content than birds and mammals. Within mammals, beluga and narwhal have the highest estimated protein per consumed fraction, contributed primarily by the dried meat component of assumed intake (bowhead has lower protein content because meat is assumed to be not consumed; Table S2). Whales are, collectively, also among the most energy rich country food items, along with seals and goose eggs (Fig. 2a), presumably because of their high lipid content. Char and caribou are both relatively low in energy content, but high in protein (though this partly reflects our assumption that the consumed portion of char and caribou is predominately muscle).

Comparing the energy and protein available in reported harvest to the RDA indicates that 17 of 21 Nunavut 

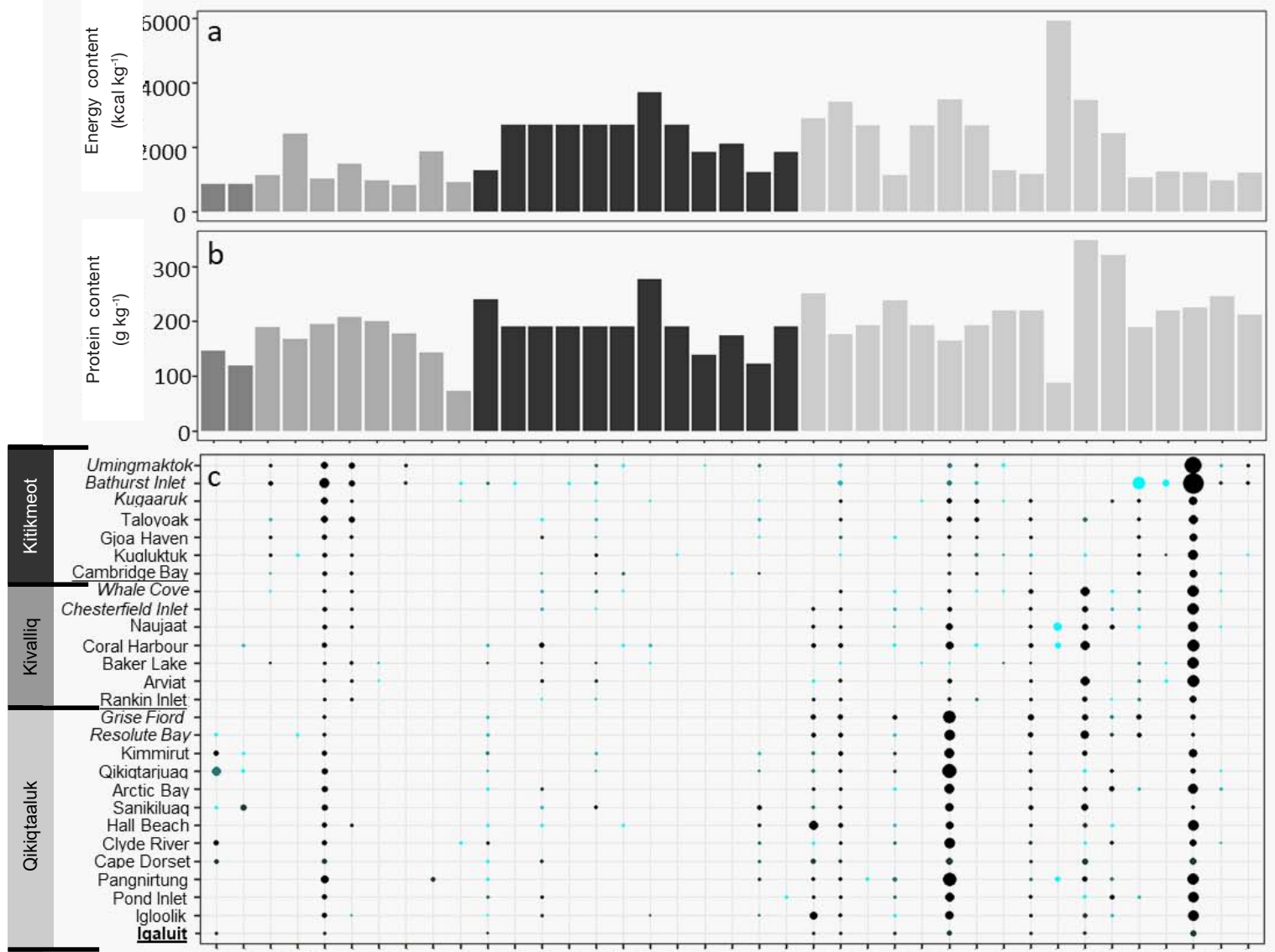

Country

Food

Harvest

Edible

Yield

(kg

person $^{-1}$

year $^{-1}$ )

$\therefore 1$

- 10

: 50

- 250

Years

Harvested

5
4
3

4
3
2
1

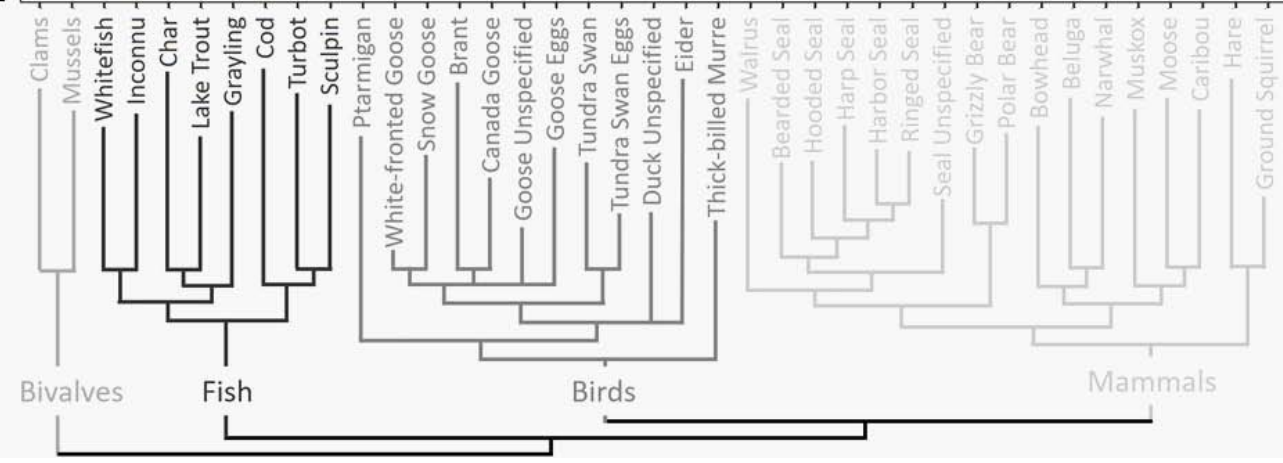

FIG. 2. Energy content (a), protein content (b), and reported edible harvest yeilds (c) of the 10 most harvested wildlife species for each Nunavut community. Nutritional content ( $\mathrm{a}$ and b) is estimated per kg serving of consumed tissues (Tables S1, S2). Species-specific harvest (c) is reported in units kg person ${ }^{-1}$ year ${ }^{-1}$. In (c), communities are grouped by region and ordered by population size (smallest communities at the top) with regional capitals at the bottom and underlined; italicized communities have reported harvest but are not included in subsequent analyses because store-bought food or income data are lacking. Wildlife species (or species categories) are ordered and dendrogram-connected according to hypothesized phylogenetic relatedness. For harvest level symbols, the blue $(1 \mathrm{yr})$ to black ( $5 \mathrm{yr}$ ) colour ramp indicates the number of years (out of the five years surveyed) that a species was among the 10 most harvested species within a given community. Phylogenetic sources used to construct the wildlife species dendogram (c) include Dunn et al. (2014) for animals, Cotton and Page (2002) for vertebrates, Hughes et al. (2018) for ray-finned fishes (Lecaudey et al., 2018 for salmonid genera), Prum et al. (2015) for birds, Eo et al. (2009) for fowl genera, and Bininda-Emonds et al. (2007) for mammals (Nyakatura and Bininda-Emonds, 2012 for carnivore genera).

communities harvest enough country food to satisfy the protein requirements of all community members, whereas only one of 21 communities harvest enough country food to satisfy everyone's energy requirements (Fig. 3; Table S3).

Across Nunavut, store-bought food prices are high relative to reported incomes (Fig. 4). The cost of a RNFB with the Nutrition North subsidy included ranges from $\$ 382.38$ per week ( $\$ 19,883.76$ annually) in Arviat to $\$ 478.19$ per week $(\$ 24,865.88$ annually) in Pangnirtung (Fig. 4a). The cost of a RNFB excluding the Nutrition North subsidy was, on average, $139 \%$ of the discounted price, ranging from $115 \%$ in Sanikiluaq to $178 \%$ in Arctic Bay. Median reported total income averaged $\$ 27,890$ across 24 Nunavut communities, ranging from $\$ 19,220$ in Sanikiluaq to $\$ 67$ 260 in Iqaluit (Fig. 4b).

Comparing annual store-bought food costs to reported incomes indicates that estimated store-bought food costs account for more than $50 \%$ of median total income in 19 of 21 Nunavut communities and more than $80 \%$ in 15 of 21 communities (Fig. 4c). This store-bought food poverty index 

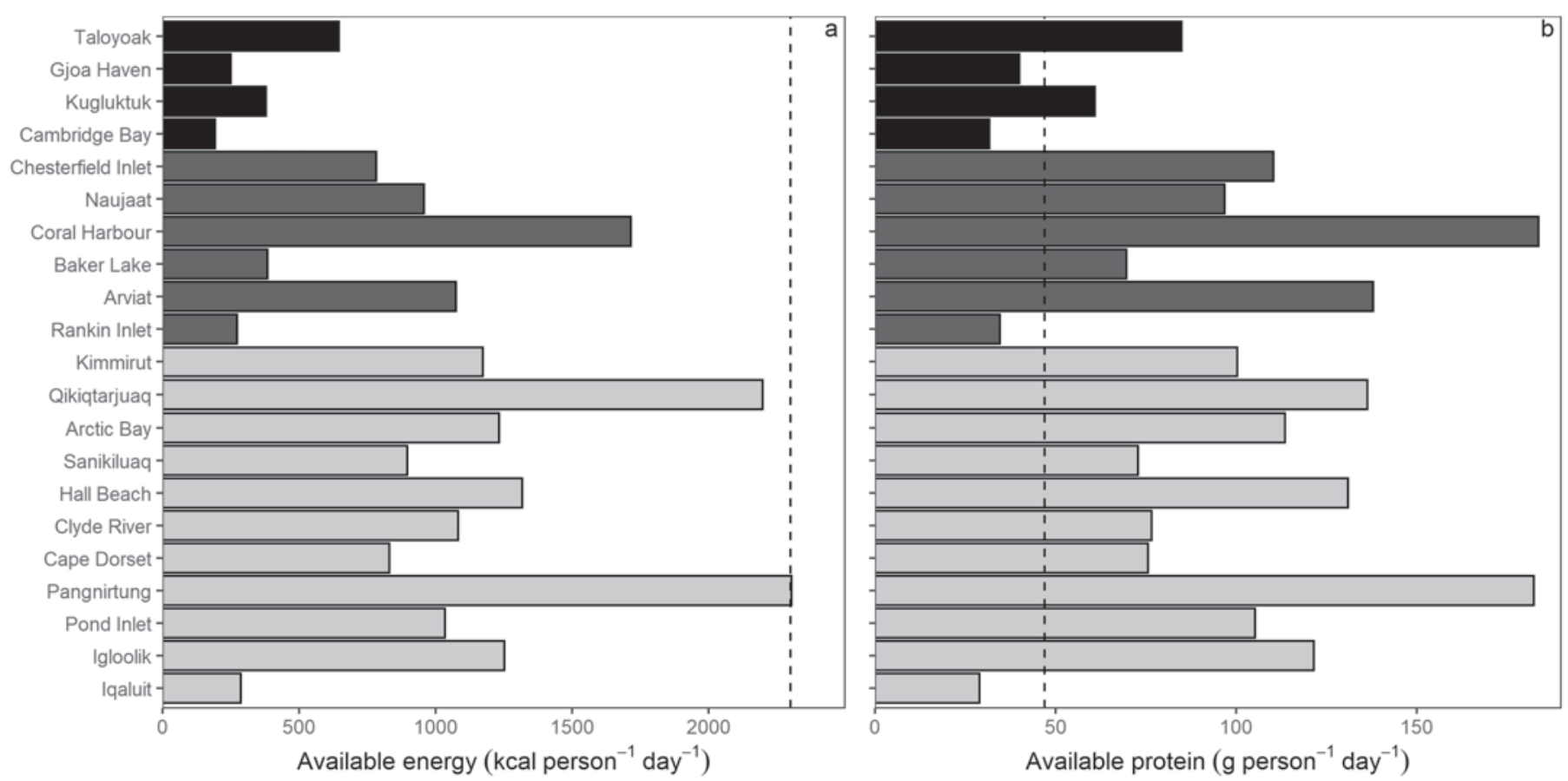

FIG. 3. Available energy (a; kcal person $\left.{ }^{-1} \mathrm{~d}^{-1}\right)$ and protein $\left(b ; g\right.$ person $\left.{ }^{-1} \mathrm{~d}^{-1}\right)$ from reported country food harvest across Nunavut regions and communities, assuming homogenous distribution and consumption of harvest. Dotted lines represent average recommended daily allowances (RDA) for energy and protein.

varied widely among communities, reaching a maximum value in Sanikiluaq where food cost is $122 \%$ of median total income and much lower (relatively more affordable) values of $32 \%$ in Iqaluit (the territorial capital) and $45 \%$ in Rankin Inlet (Kivalliq's regional capital). This poverty index was more affected by variation in income than variation in food costs, because the former varied more (from $\$ 19,220$ to $\$ 67,260$ ) than the latter (from $\$ 19,884$ to $\$ 24,866$ ).

The total country food energy harvested averaged

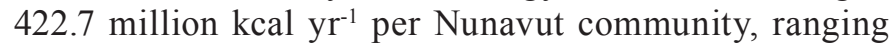

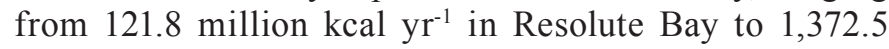
million kcal $\mathrm{yr}^{-1}$ in Pangnirtung (Fig. 5a; Table S3). The country food protein harvest averaged $43,696 \mathrm{~kg} \mathrm{yr}^{-1}$ per Nunavut community, ranging from (among data-complete communities), $16,472 \mathrm{~kg} \mathrm{yr}^{-1}$ in Kimmirut to $139,676 \mathrm{~kg}$ $\mathrm{yr}^{-1}$ in Arviat (Fig. 5e; Table S3). Given a RNFB that was estimated to contain 69,419.6 kcal of energy and 3,097.1 $\mathrm{g}$ of protein, the energy cost of store-bought food across Nunavut communities averages $\$ 0.0062 \mathrm{kcal}^{-1}$, ranging from $\$ 0.0055 \mathrm{kcal}^{-1}$ in Arviat to $\$ 0.0069$ in Pangnirtung (or excluding the Nutrition North subsidy, averages $\$ 0.0087$ $\mathrm{kcal}^{-1}$ and ranges from $\$ 0.0066$ in Arviat to $\$ 0.0118$ in Arctic Bay; Fig. 5b) and the protein cost of store-bought food in Nunavut averages $\$ 0.140 \mathrm{~g}^{-1}$, ranging from $\$ 0.123$ $\mathrm{g}^{-1}$ in Arviat to $\$ 0.154 \mathrm{~g} \mathrm{~g}^{-1}$ in Pangnirtung (or excluding the Nutrition North subsidy, averages $\$ 0.195 \mathrm{~g}^{-1}$ and ranges from $\$ 0.148$ in Arviat to $\$ 0.265$ in Arctic Bay; Fig. 5f; Table S3).

Multiplying country food total energy harvested

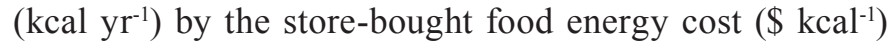
indicates a country food energy replacement value ranging from $\$ 736,127 \mathrm{yr}^{-1}$ in Cambridge Bay to $\$ 9.454$ million $\mathrm{yr}^{-1}$ in Pangnirtung, totalling $\$ 63.215$ million $\mathrm{yr}^{-1}$ across all of Nunavut (or excluding the Nutrition North subsidy, $\$ 857.724$ in Cambridge Bay, $\$ 12.757$ million $\mathrm{yr}^{-1}$ in Pangnirtung, and totalling $\$ 87.889$ million $\mathrm{yr}^{-1}$ across all of Nunavut; Fig. 5c, d). Multiplying country food total protein harvested $\left(\mathrm{kg} \mathrm{yr}^{-1}\right)$ by the store-bought food protein cost $\left(\$ \mathrm{~kg}^{-1}\right)$ indicates a country food protein replacement value ranging from $\$ 2.301$ million $\mathrm{yr}^{-1}$ in Kimmirut to $\$ 17.242$

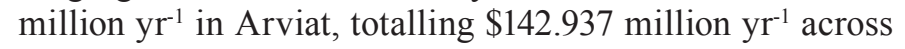
all of Nunavut (or excluding the Nutrition North subsidy, \$3.168 million $\mathrm{yr}^{-1}$ in Cambridge Bay, \$22.665 million $\mathrm{yr}^{-1}$ in Pangnirtung, totalling $\$ 198.845$ million $\mathrm{yr}^{-1}$ across all of Nunavut; Fig. 5g, h; Table S4).

Comparing indices highlighting country food wealth to those indicative of store-bought food poverty emphasizes a general pattern across Nunavut regions and communities - many smaller, more remote or more traditional Nunavut communities appear to offset storebought food poverty with country food wealth, whereas the territorial capital of Iqaluit, and the regional capitals of Rankin Inlet and Cambridge Bay have less country food wealth but greater affordability of store-bought food (Fig. 6). Communities that are partial exceptions to this pattern include Chesterfield Inlet and Arviat with higher than average store-bought food affordability and considerable country food wealth, and Gjoa Haven and to a lesser extent Sanikiluaq, which are characterized by low store-bought food affordability and limited country food wealth.

According to average energy and protein content of the consumed fraction of country food and its estimated storebought food replacement value, a $1 \mathrm{~kg}$ serving of typical Nunavut country food has an energy value of $\$ 13.19 \mathrm{~kg}^{-1}$ (or 

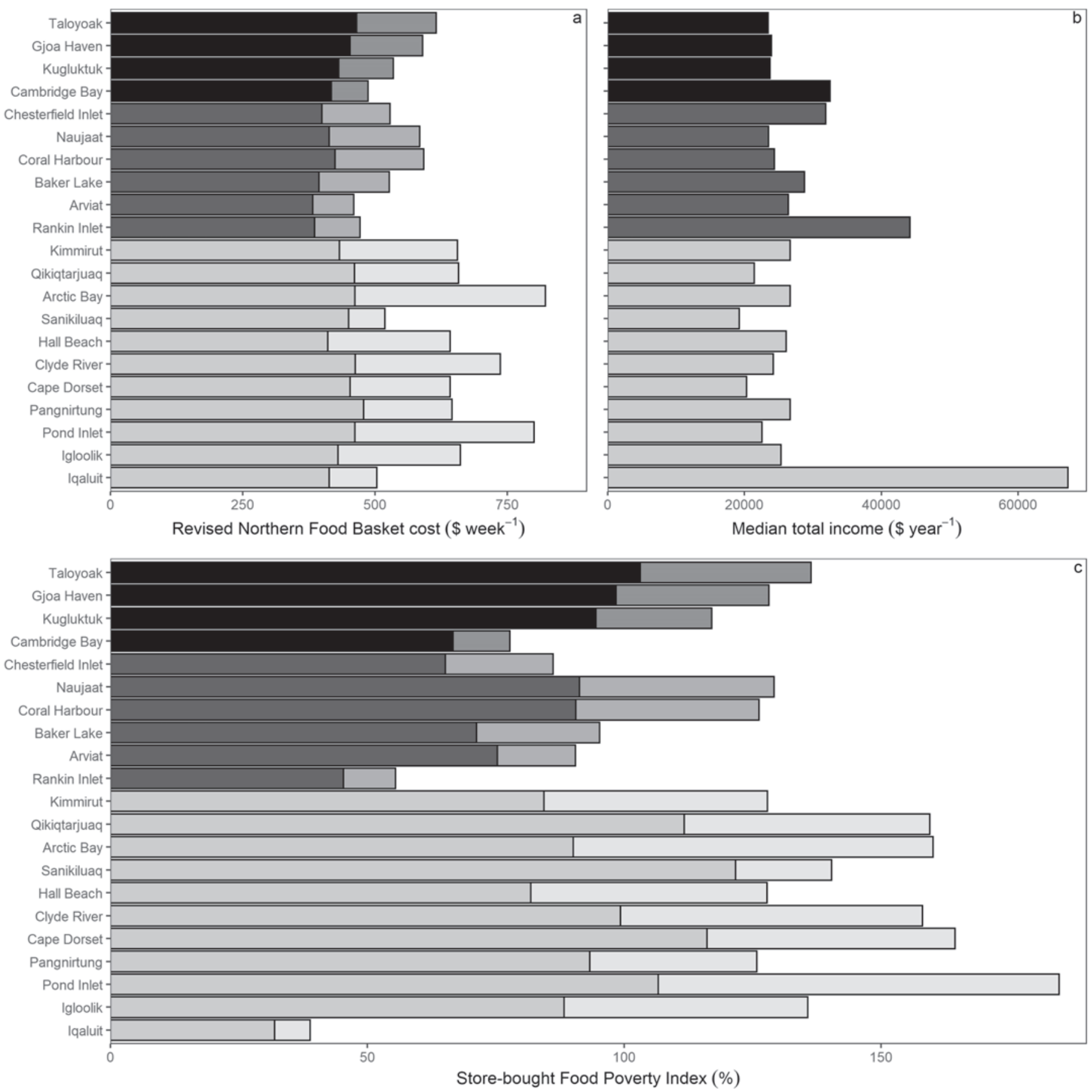

FIG. 4. Store-bought food poverty in Nunavut communities, based on (a) the weekly cost of a revised northern food basket (RNFB; $\$$ week ${ }^{-1}$ ) reported for each community in 2016, including the discount provided by the Nutrition North subsidy (darker bar) or with this subsidy excluded (lighter bar), and (b) median total income $\left(\$ \mathrm{y}^{-1}\right)$. Expressing the cost of $52 \mathrm{RNFB}$ as a percentage of median reported income generates (c) a store-bought food poverty index, which assumes a four-person household supported by a single reported total income.

$\$ 17.53 \mathrm{~kg}^{-1}$ excluding subsidy) and a protein value of $\$ 30.17$ $\mathrm{kg}^{-1}$ (or $\$ 39.67 \mathrm{~kg}^{-1}$ excluding subsidy). Protein-replacement values and, in particular, protein-replacement values excluding the Nutrition North subsidy, are higher than most if not all previous estimates of local food value (Table 1).

Based on an average country food value of $\$ 39.67 \mathrm{~kg}$ $\mathrm{yr}^{-1}$ and 5 million $\mathrm{kg} \mathrm{yr}^{-1}$ country food harvest across the territory, Nunavut's country food system annually harvests protein that would cost nearly $\$ 200$ million to purchase in grocery stores (Fig. 5h). In 2016, Nunavut reported \$2.27 billion in GDP, $\$ 620$ million of which was attributed to natural resource sectors. Comparing our $\$ 150-200$ million replacement value estimate to the $\$ 3.5$ million reported for the hunting, fishing, and trapping sector or to the Government of Nunavut (2021) estimated replacement value of $\$ 35$ million for the country food economy suggests the value of wildlife harvest to Nunavummiut and the Nunavut economy may be underestimated by two to three orders of magnitude. 

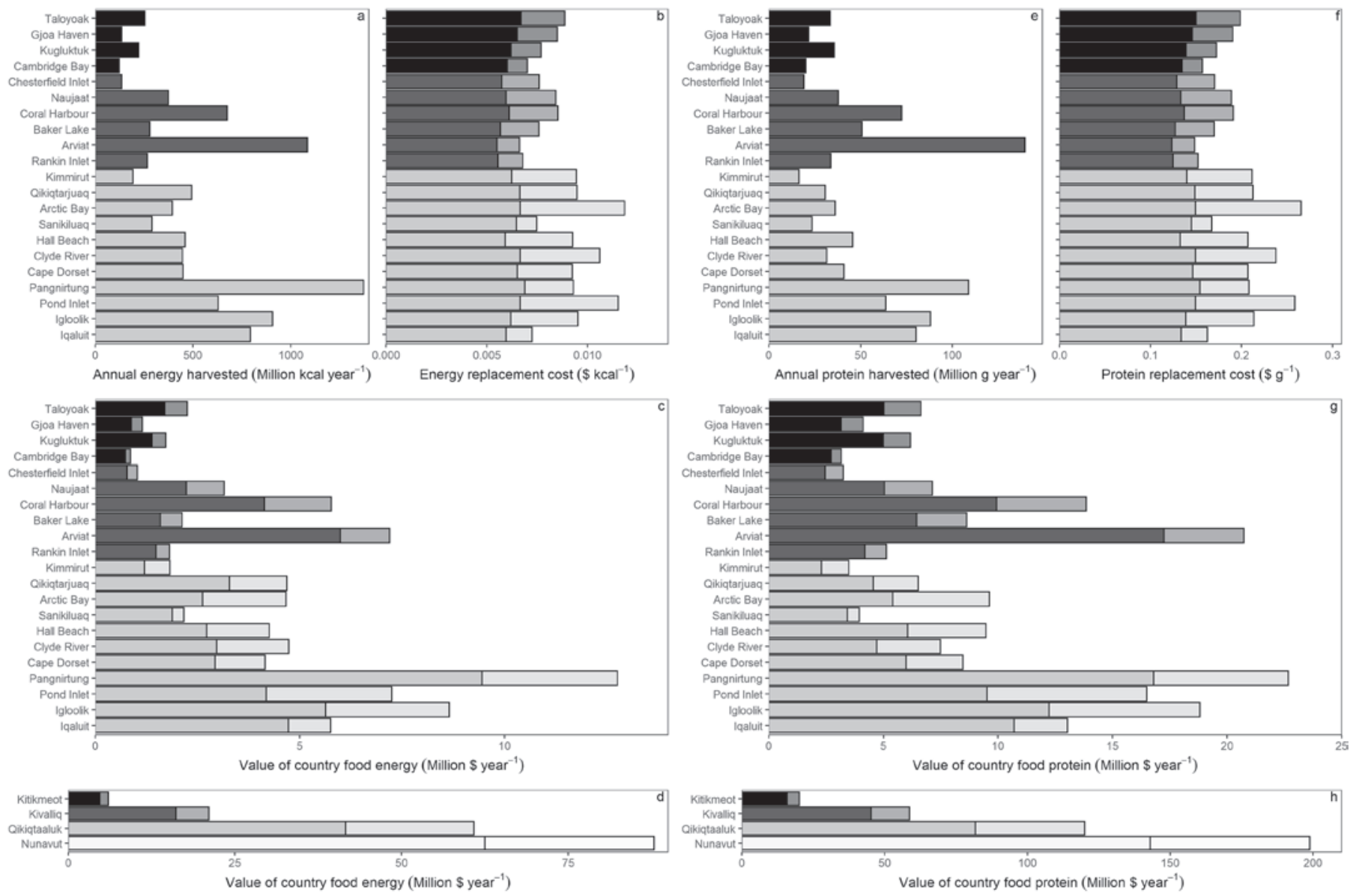

FIG. 5. Valuation of annual country food harvest across Nunavut communities and regions based on energy (a-d) and protein replacement (e-h). a) Annual energy harvested (million $\mathrm{kcal} \mathrm{yr}^{-1}$ ) derived from reported country food harvest, edible yield, and energy content of edible fraction. b) Store-bought food energy replacement cost, expressed as $\$ \mathrm{kcal}^{-1}$, based on the cost and energy content of a revised northern food basket, including Nutrition North subsidy (darker bar) and excluding subsidy (lighter bar). c) Replacement value of country food energy by community (million $\$$ yr $^{-1}$ ), calculated as a product of (a) and (b), including (darker bar) and excluding (lighter bar) Nutrition North subsidy. d) Summed regional and territorial country food energy value (million $\left.\$ \mathrm{yr}^{-1}\right)$. e-h) present equivalent information for protein replacement, including e) protein harvested (million $\left.\mathrm{g} \mathrm{yr}^{-1}\right), \mathrm{f}$ ) store-bought food protein replacement cost $\left(\$ \mathrm{~g}^{-1}\right)$, $\mathrm{g}$ ) country food protein value by community (million $\$ \mathrm{yr}^{-1}$ ), and $\mathrm{h}$ ) regional and territorial totals (million $\$ \mathrm{yr}^{-1}$ ).

\section{DISCUSSION}

Valuation of Nunavut's country food system, according to local prices of store-bought food required to replace harvested nutrients, indicates a territorial average replacement value of $\$ 13 \mathrm{~kg}^{-1}$ for the energy and $\$ 30 \mathrm{~kg}^{-1}$ for the protein contained in country foods. Values increase to $\$ 18 \mathrm{~kg}^{-1}$ for energy and $\$ 40 \mathrm{~kg}^{-1}$ for protein when store-bought food costs are not discounted by the Nutrition North subsidy programs. These valuations are higher than most financial values previously estimated for local food harvests (Usher, 1971; DeLury et al., 1975; Berkes et al., 1994; Wenzel, 2009; Pal et al., 2013) because they are more reflective of the energy and nutrient richness of country food (InterGroup Consultants Ltd., 2013) and the high and subsidized price of store-bought food in northern communities.

Scaling the $\$ 40 \mathrm{~kg}^{-1}$ country food value across the totality of wildlife harvests documented during the fiveyear NWHS indicates the Nunavut country food system harvests protein worth $\$ 198$ million annually, dwarfing the $\$ 3.5$ million annual valuation applied to the hunting, fishing, and trapping sector by the Nunavut Bureau of Statistics. GDP-based valuation of natural resource sectors emphasizes the contributions of mining and oil and gas ( $>$ $\$ 500$ million in 2016, combined) to the Nunavut economy (GN, 2019), but the country food system may be more likely to generate wealth that stays in the territory and that is welldistributed across regions and households (Bernauer, 2019). Converting community-specific harvest data into nutrient yield indicates that the annual harvest of country food in Nunavut is sufficient to meet the RDA of protein for the entire population and about $50 \%$ of the population's energy requirements. Thus, our results converge with previous analyses of the NWHS, particularly Lysenko and Schott's (2019) demonstration of wildlife harvest contributions to food security and the importance of the mixed economy in the Nunavut food system.

The valuation approach described here, based on an integration of data sources related to country food (harvest amounts, edible yield, and nutrient composition) and storebought food (food basket costs, nutrient composition, and subsidization levels), has several important limitations. 

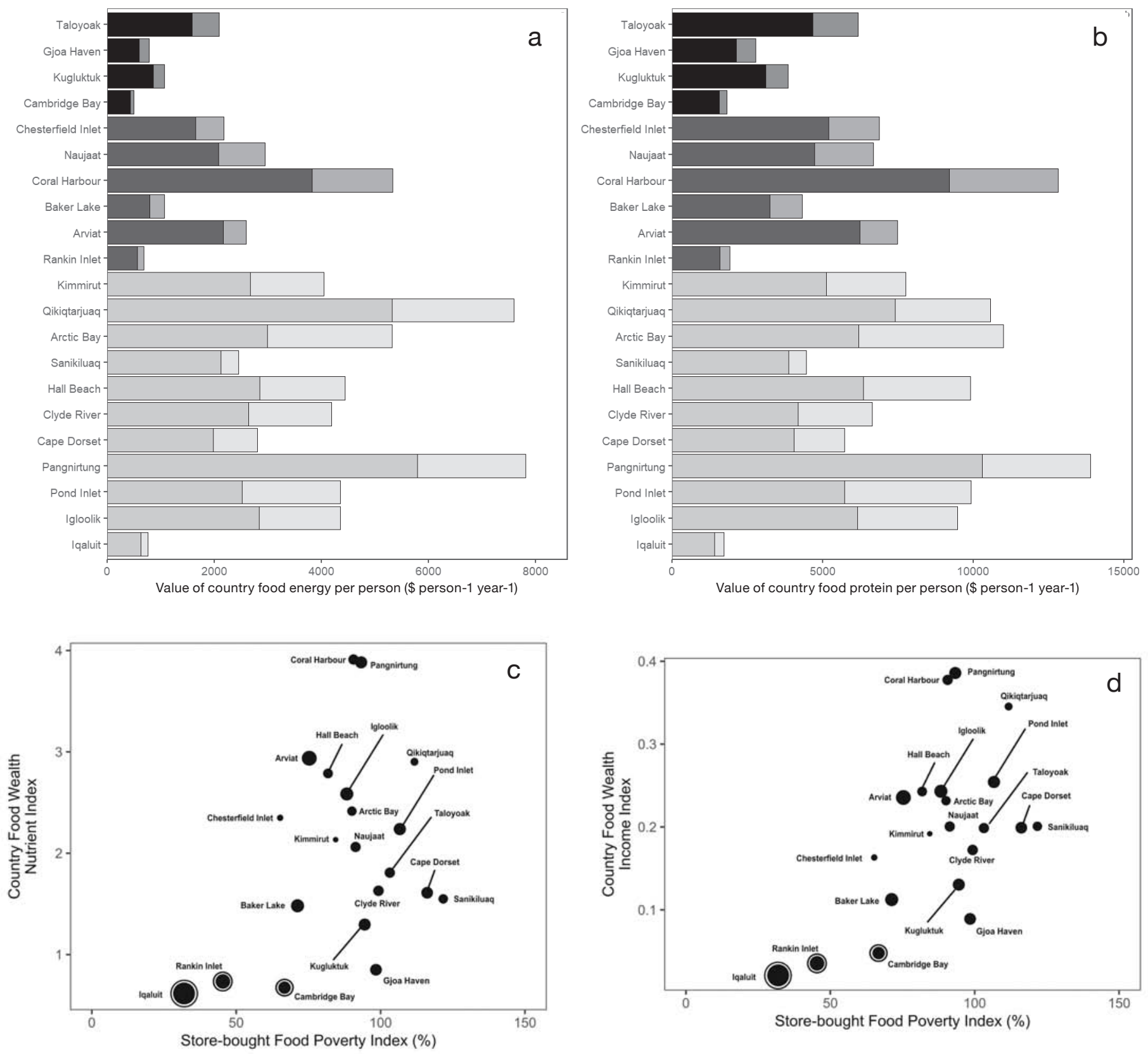

FIG. 6. Per capita valuation of annual country food harvest across Nunavut communities based on (a) energy and (b) protein replacement, and country food wealth and store-bought food poverty for Nunavut communities (c, d); size of symbol indicates population size and white outline indicates capitals (as in Fig. 1). The store-bought food poverty index reflects the cost of 52 store-bought food baskets (RNFB) expressed as a percentage of the median reported total income and is plotted in relation to two indices of country food wealth. (c) A country food wealth nutrition index focused here on harvested protein $\left(\mathrm{g} \mathrm{person}^{-1} \mathrm{~d}^{-1}\right)$ expressed as a proportion or multiple of the recommended dietary allowance (RDA) for protein ( $\left(\right.$ person $\left.^{-1} \mathrm{~d}^{-1}\right)$, and (d) a country food wealth income index focused here on the value of harvested protein $\left(\$ \mathrm{pc}^{-1} \mathrm{yr}^{-1}\right)$ expressed as a proportion of median annual reported income $\left(\$ \mathrm{yr}^{-1}\right)$.

First, the NWHS harvest data represent reported harvests from 1996 to 2000. As is the case for all harvest surveys, reported harvest may not reflect actual harvest, and harvest levels are likely to change over time (Wenzel et al., 2016). For example, since the completion of the NWHS, most Nunavut caribou herds have declined dramatically, leading to caribou harvest restrictions (quotas or bans) and reduced caribou consumption, with presumed but poorly documented impacts on the rest of the Nunavut country food system (Kenny et al., 2018b). The socio-ecological system of Nunavut, specifically wildlife regimes, can mean that local food security is sensitive to both local ecology, but also regional harvest policies, which stresses the importance of long-term projects monitoring dietary change (Redwood et al., 2019). The population of Nunavut has also grown in this timeframe; the NWHS quotes the Inuit population of Nunavut at 22,947 in 1999 (Priest and Usher, 2004), while the 2016 Canadian census reported 30,140 Inuit residents of Nunavut (Statistics Canada, 2017). The increasing population poses the risk of further 
TABLE 1. Country food system valuations, expressed as $2016 \$ \mathrm{~kg}^{-1}$, comparing our nutrient replacement-based valuations based on protein or energy (with or without the Nutrition North subsidy) to prior valuations based on mass replacement or exchange value.

\begin{tabular}{llll}
\hline \hline Value $\left(\$ \mathrm{~kg}^{-1}\right)$ & Basis of valuation & Region & Source \\
\hline 39.67 & Protein replacement, local store-bought food cost, unsubsidized & Nunavut & Current study \\
35.52 & Mass replacement, local store-bought food cost & Yukon & DeLury et al., 1975 \\
30.17 & Protein replacement, local store-bought food cost, subsidized & Nunavut & Current study \\
18.86 & Mass replacement, local store-bought food cost & James Bay and Hudson Bay, Ontario & Berkes et al., 1994 \\
17.61 & Not clearly described in source & Alaska & O'Garra, 2017 \\
17.53 & Energy replacement, local store-bought food cost, unsubsidized & Nunavut & Current study \\
13.19 & Energy replacement, local store-bought food cost, unsubsidized & Nunavut & Current study \\
17.81 & Not clearly described in source & Nunavut & Wenzel, 2009 \\
9.41 & Mass replacement, local store-bought food cost & Fort Severn, Ontario & Pal et al., 2013 \\
3.12 & In community barter/exchange value & Banks Island, NWT & Usher, 1971 \\
\hline \hline
\end{tabular}

challenging food security in the region, requiring either increased total harvest levels or sharing less country food among more people if total harvest remains constant or declines. The complexity of the food system again underlines calls to ensure food security and wildlife management policy are treated in tandem, with health policy and wildlife management considered in relation to each other (Kenny et al., 2018b; Lysenko and Schott, 2019). Harvest surveys also exclude critical information on postharvest processing, sharing, preparation, and consumption of food, which collectively define the extent and distribution of country food nutrition. Assumptions regarding edible yield fractions and nutrient composition of specific tissues have received considerable research attention and have been recently shown to yield estimates of intake that correspond well with food frequency surveys (Kenny and Chan, 2017). Nevertheless, the distinction between what is reported harvested and the actual food amounts and tissues consumed and by whom remains a key knowledge gap in harvest-based food valuations.

Data on the price and nutritional value of store-bought foods in northern communities has improved over time, but key uncertainties remain, including seasonal variation in the cost and availability of store-bought food, the consumer impact of store-bought food subsidies across a series of program transitions (Duhaime and Édouard, 2015; Galloway, 2017; St-Germain et al., 2019), and three issues related to the replaceability of harvested nutrients using store-bought food (see also Kenny et al., 2018c). The first replacement issue is whether energy and protein replacement should be valued separately (i.e., food value $=$ protein value or energy value) as we have done here, or additively (i.e., food value $=$ protein value + energy value), which would be more appropriate if the protein and energy content of country foods are replaced independently through the purchase of separate foods.

A second, related replacement issue involves the combination of store-bought food items used to substitute country food. Our valuation assumes the substitution occurs via the purchase of a RNFB, because this collection of items is intended to reflect healthy store-bought food and because price and nutritional data are available for these items. Actual substitutions may be more or less strategic. For example, if in-store food purchases target foods that are more nutritious (i.e., contain more protein and energy) and less expensive than the RNFB average, then our country food valuation may be an overestimate (because people will have obtained more store-bought protein and energy at less cost than we have estimated). Conversely, if store-bought foods are typically less nutritious or more expensive than the RNFB, then we may have underestimated the value of country food. The literature about traditional food systems tends to highlight the contribution these foods make to essential dietary nutrients and the relative nutrient richness of these foods over alternatives (Kuhnlein and Receveur, 2007; Rosol et al., 2016; Kenny et al., 2018a, b, c).

Third, our replacement valuation considers only energy and protein replacement and thus excludes consideration of all the additional macronutrients and micronutrients acquired through or associated with country food, such as iron, zinc, and potassium (Receveur et al., 1997; Kuhnlein and Receveur, 2007; Blanchet and Rochette, 2008; Egeland et al., 2011; Rosol et al., 2016), as well as all the values of country food beyond nutrition, including sharing, knowledge, culture, well-being, and identity (Borré, 1991; Condon et al., 1995; Kuhnlein et al., 2004; Lambden et al., 2007). The non-nutritional benefits of country foods have been estimated to represent several multiples of their nutritional value (O'Garra, 2017), but are difficult to quantify, precisely because of their lack of substitutability and their irreplaceability. Country food is, in many and important ways, priceless.

This study emphasizes the country food wealth of Nunavut communities and the enormity of country food contributions to nutrition and food security in the region. Country food is also culturally relevant food, an essential attribute that is deliberately incorporated in the very definition of food security (FAO, 1996). Food affordability is a globally recognized barrier to food security, with food costs that exceed $80 \%$ of income indicative of severe food poverty (Lee et al., 2013). Averaged across Nunavut communities, the purchase of store-bought food for a family of four for one year $(52 \mathrm{RNFB}=\$ 22,489)$ requires $81 \%$ of a single median income (Nunavut community average $=\$ 27,890)$. This store-bought food poverty index increases to $94 \%$ when averaged across Nunavut communities other than the regional and territorial capitals of Iqaluit, Rankin Inlet, and Cambridge Bay, where reported incomes are 
higher (\$67,200, $\$ 44,000$, and $\$ 32,540$, respectively), food costs are lower $(\$ 21,486, \$ 20,067$, and $\$ 21,708$, respectively) and the index therefore more favourable $(32 \%, 45 \%$, and $67 \%$, respectively). The presented measures of food affordability are sensitive to the assumed four-person household supported by a single median income earned in a region where household crowding and unemployment are high (Minich et al., 2011). Our analysis is based on a 3:1-dependant:income ratio family unit and will be sensitive to fluctuation in this ratio caused by housing circumstances; increases in the ratio of dependents will cause lower food affordability as family income is stretched thinner. Lysenko and Schott (2019) have explicitly emphasized food security metrics that can capture the particularities of a mixed food system in Nunavut, combining traditional harvesting, food sharing, wage income, and store-bought food affordability. Improving measures of food poverty require reducing the price of store-bought food, increasing incomes, or both. The Nutrition North federal subsidy program already reduces the cost of store-bought food in Nunavut by about $28 \%$. In the absence of this subsidy program, the food poverty index averaged across all Nunavut communities would be $122 \%$ and that of Nunavut communities excluding regional capitals would be $133 \%$. However, alternative measures of food poverty and food wealth are needed in Nunavut and other regions where store-bought food is not the only food, and reported incomes are not the only form of community and household wealth (see Lysenko and Schott, 2019 for further discussion of food poverty).

An Inuktitut word for country food, niqituinnaq, which translates as real food, emphasizes the primary importance of food that does not come from the store (Wenzel, 1991, 2016). Our results, including country food wealth nutrition and income indices, highlight the magnitude of country food wealth across Nunavut communities and the concentration of country food wealth within communities characterized by the most extreme store-bought food poverty. Importantly, the country food valuations we present here are gross values that do not incorporate the financial and equipment costs of harvest. Hunting in Nunavut is expensive, and financial barriers to country food access can be as important and severe as the financial barriers to store-bought food. Country food may be priceless, but it is not free; maintaining and improving access to country foods also requires financial resources. The availability of certain country food species is affected by natural variation in population levels, and food security planning must account for this. The literature indicates that communities consuming a diverse diet are best able to adapt to the loss or reduction in harvest levels of one species (Beaumier et al., 2015). Traditional knowledge across a range of harvested species has also been shown to assist climate change adaptation by permitting the harvest of alternative species when the abundance or access to a primary species declines (Ford et al., 2008; Wenzel, 2009).

The methods of country food valuation described here should be applicable to other regions within Inuit
Nunangat and to the traditional and local food systems of Indigenous cultures living elsewhere in North America and across the globe. Several authors have now stressed the importance of describing Indigenous food security in a manner that accommodates the importance of local food alongside many other systematic elements contributing to household food security (Kenny et al., 2018b; Lysenko and Schott, 2019). Money does not define the country food system, but given the wealth country foods represent and the biocultural opportunity for sustained use of renewable resources for remote, northern regions, financial investment in the country food system, ranging from harvester income support to effective wildlife conservation, may be as or more effective than efforts focused on improving the affordability of store-bought food.

\section{ACKNOWLEDGEMENTS}

The authors would like to thank David Lee, Amy Caughey, and George Wenzel for their comments on the manuscript, Stephanie Lacoste for assistance with data management, and John Colford from the Government of Northwest Territories, who helped us appreciate the value of local food systems and the opportunity to communicate this value through comparison to store-bought food prices.

\section{REFERENCES}

Abson, D.J., von Wehrden, H., Baumgärtner, S., Fischer, J., Hanspach, J., Härdtle, W., Heinrichs, H., et al. 2014. Ecosystem services as a boundary object for sustainability. Ecological Economics 103:29-37.

https://doi.org/10.1016/j.ecolecon.2014.04.012

Bank of Canada. 2019. Inflation calculator. Ottawa: Bank of Canada.

https://www.bankofcanada.ca/rates/related/inflationcalculator/

Beaumier, M., Ford, J.D., and Tagalik, S. 2015. The food security of Inuit women in Arviat, Nunavut: The role of socio-economic factors and climate change. Polar Record 51(5):550-559.

https://doi.org/10.1017/S0032247414000618

Berkes, F., George, P.J., Preston, R.J., Hughes, A., Turner, J., and Cummins, B.D. 1994. Wildlife harvesting and sustainable regional native economy in the Hudson and James Bay Lowland, Ontario. Arctic 47(4):350-360.

https://doi.org/10.14430/arctic1308

Bernauer, W. 2019. The limits to extraction: Mining and colonialism in Nunavut. Canadian Journal of Development Studies 40(3):404-422. https://doi.org/10.1080/02255189.2019.1629883

Bininda-Emonds, O.R.P., Cardillo, M., Jones, K.E., MacPhee, R.D.E., Beck, R.M.D., Grenyer, R., Price, S.A., Vos, R.A., Gittleman, J.L., and Purvis, A. 2007. The delayed rise of present-day mammals. Nature 446:507-512.

https://doi.org/10.1038/nature05634 
Blanchet, C., and Rochette, L. 2008. Qanuippitaa? How are we? Nutrition and food consumption among the Inuit of Nunavik. Québec City, Québec: Institut national de santé publique du Québec and Kuujjuaq, Québec: Nunavik Regional Board of Health and Social Services.

Borré, K. 1991. Seal blood, Inuit blood, and diet: A biocultural model of physiology and cultural identity. Medical Anthropology Quarterly 5(1):48-62. https://doi.org/10.1525/maq.1991.5.1.02a00080

Burow, P.B., Brock, S., and Dove, M.R. 2018. Unsettling the land: Indigeneity, ontology, and hybridity in settler colonialism. Environment and Society 9(1):57-74. https://doi.org/10.3167/ares.2018.090105

Caine, K.J., and Krogman, N. 2010. Powerful or just plain powerfull? A power analysis of impact and benefit agreements in Canada's North. Organization \& Environment 23(1):76-98. https://doi.org/10.1177/1086026609358969

Carter, N., Dawson, J., and Cook, A. 2019. Arctic corridors and northern voices: Governing marine transportation in the Canadian Arctic (Resolute, Nunavut community report). Ottawa, Ontario: University of Ottawa. https://doi.org/10.20381/ruor39361

CCA (Council of Canadian Academies). 2014. Aboriginal food security in northern Canada: An assessment of the state of knowledge. Ottawa, Ontario: Expert Panel on the State of Knowledge of Food Security in Northern Canada, CCA.

https://cca-reports.ca/wp-content/uploads/2018/10/ foodsecurity_fullreporten.pdf

Chabot, M. 2003. Economic changes, household strategies, and social relations of contemporary Nunavik Inuit. The Polar Record 39(1):19-34. https://doi.org/10.1017/S0032247402002711

Champalle, C., Ford, J.D., and Sherman, M., 2015. Prioritizing climate change adaptations in Canadian Arctic communities. Sustainability 7(7): 9268-9292. https://doi.org/10.3390/su7079268

Chan, H.M., Fediuk, K., Hamilton, S., Rostas, L., Caughey, A., Kuhnlein, H., Egeland, G., and Loring, E. 2006. Food security in Nunavut, Canada: Barriers and recommendations. International Journal of Circumpolar Health 65(5):416-431. https://doi.org/10.3402/ijch.v65i5.18132

Condon, R.G., Collings, P., and Wenzel, G. 1995. The best part of life: Subsistence hunting, ethnicity, and economic adaptation among young adult Inuit males. Arctic 48(1):31-46. https://doi.org/10.14430/arctic1222

Conger, A.O., and Magdanz, J. 1990. The harvest of fish and wildlife in three Alaska communities: Brevig Mission, Golovin, and Shishmaref. Juneau: Alaska Department of Fish and Game, Division of Subsistence.

Cotton, J.A., and Page, R.D.M. 2002. Going nuclear: Gene family evolution and vertebrate phylogeny reconciled. Proceedings of the Royal Society B: Biological Sciences 269(1500):1555 - 1561. https://doi.org/10.1098/rspb.2002.2074
DeLury, R.T., Steigenberger, L.W., and Elson, M.S. 1975. Aspects of the historical and present day fisheries exploitation in the northern Yukon Territory. In: Steigenberger, L.W., Elson, M.S., and DeLury, R.T., eds. Northern Yukon Fisheries Studies, 1971-1974, Vol. I. PAC/T-75-19. Environmental-Social Committee, Northern Pipelines, Task Force on Northern Oil Development. Ottawa, Ontario: Environment Canada, Fisheries and Marine Service. ix $+66 \mathrm{p}$.

https://waves-vagues.dfo-mpo.gc.ca/Library/15008.pdf

Dudley, J.P., Hoberg, E.P., Jenkins, E.J., and Parkinson, A.J. 2015. Climate change in the North American Arctic: A one health perspective. EcoHealth 12:713-725. https://doi.org/10.1007/s10393-015-1036-1

Duhaime, G., and Édouard, R. 2015. Monetary poverty in Inuit Nunangat. Arctic 68(2):223-232.

https://doi.org/10.14430/arctic4481

Dunn, C.W., Giribet, G., Edgecombe, G.D., and Hejnol, A. 2014. Animal phylogeny and its evolutionary implications. Annual Review of Ecology, Evolution, and Systematics 45:371-395. https://doi.org/10.1146/annurev-ecolsys-120213-091627

Egeland, G.M., Johnson-Down, L., Cao, Z.R., Sheikh, N., and Weiler, H.A. 2011. Food insecurity and nutrition transition combine to affect nutrient intakes in Canadian Arctic communities. The Journal of Nutrition 141(9):1746-1753. https://doi.org/10.3945/jn.111.139006

Eo, S.H., Bininda-Emonds, O.R.P., and Carroll, J.P. 2009. A phylogenetic supertree of the fowls (Galloanserae, Aves). Zoologica Scripta 38(5):465-481. https://doi.org/10.1111/j.1463-6409.2008.00382.x

Fall, J.A. 2014. Subsistence in Alaska: A year 2012 update. Anchorage: Division of Subsistence, Alaska Department of Fish and Game.

FAO (Food and Agriculture Organization). 1996. Rome declaration on world food security and world food summit plan of action. World Food Summit 13 - 17 November 1996, Rome. https://digitallibrary.un.org/record/195568? $1 \mathrm{ln}=\mathrm{en}$

Ford, J.D., and Berrang-Ford, L. 2009. Food security in Igloolik, Nunavut: An exploratory study. Polar Record 45(3):225-236. https://doi.org/10.1017/S0032247408008048

Ford, J.D., Smit, B., Wandel, J., Allurut, M., Shappa, K., Ittusarjuat, H., and Qrunnut, K. 2008. Climate change in the Arctic: Current and future vulnerability in two Inuit communities in Canada. The Geographical Journal 174(1):45-62. https://doi.org/10.1111/j.1475-4959.2007.00249.x

Ford, J.D., Cunsolo Willox, A., Chatwood, S., Furgal, C., Harper, S., Mauro, I., and Pearce, T. 2014. Adapting to the effects of climate change on Inuit health. American Journal of Public Health 104(S3):e9-e17. https://doi.org/10.2105/AJPH.2013.301724

Furgal, C., and Seguin, J. 2006. Climate change, health, and vulnerability in Canadian northern Aboriginal communities. Environmental Health Perspectives 114(12):1964-1970. https://doi.org/10.1289/ehp.8433

Galloway, T. 2017. Canada's northern food subsidy Nutrition North Canada: A comprehensive program evaluation. International Journal of Circumpolar Health 76(1): 1279451 https://doi.org/10.1080/22423982.2017.1279451 
GC (Government of Canada). 2017. Nutrition North Canada engagement 2016: Final report of what we heard. Ottawa: Nutrition North Canada, GC.

www.nutritionnorthcanada.gc.ca/eng/1491505202346/ 1491505247821

Gómez-Baggethun, E., and Ruiz-Pérez, M. 2011. Economic valuation and the commodification of ecosystem services. Progress in Physical Geography: Earth and Environment 35(5):613-628.

https://doi.org/10.1177/0309133311421708

GN (Government of Nunavut). 2019. Economic data. Iqaluit: Department of Executive and Intergovernmental Affairs, Nunavut Statistics.

https://www.gov.nu.ca/executive-and-intergovernmentalaffairs/information/economic-data

___ 2021. Nunavut economy. Iqaluit: Department of Executive and Intergovernmental Affairs.

https://www.gov.nu.ca/eia/documents/nunavut-economy

Harder, M.T., and Wenzel, G.W. 2012. Inuit subsistence, social economy and food security in Clyde River, Nunavut. Arctic 65(3):305-318.

https://doi.org/10.14430/arctic4218

Health Canada. 2010. Dietary reference intakes tables. Ottawa: Health Canada, Government of Canada.

https://www.canada.ca/en/health-canada/services/foodnutrition/healthy-eating/dietary-reference-intakes/tables.html 2018. Canadian nutrient file (CNF): Search by food. https://food-nutrition.canada.ca/cnf-fce/index-eng.jsp

Hjort, J., Karjalainen, O., Aalto, J., Westermann, S., Romanovsky, V.E., Nelson, F.E., Etzelmüller, B., and Luoto, M. 2018. Degrading permafrost puts Arctic infrastructure at risk by mid-century. Nature Communications 9: 5147.

https://doi.org/10.1038/s41467-018-07557-4

Hughes, L.C., Ortí, G., Huang, Y., Sun, Y., Baldwin, C.C., Thompson, A.W., Arcila, D., et al. 2018. Comprehensive phylogeny of ray-finned fishes (Actinopterygii) based on transcriptomic and genomic data. Proceedings of the National Academy of Sciences 115(24):6249-6254.

https://doi.org/10.1073/pnas.1719358115

InterGroup Consultants Ltd. 2013. Economic valuation and sociocultural perspectives of the estimated harvest of the Beverly and Qamanirjuaq caribou herds, rev. version. Submitted to: Beverly and Qamanirjuaq Caribou Management Board, PO Box 629, Stonewall, Manitba R0C 2Z0, Canada.

https://arctic-caribou.com/pdf/CaribouEconomicValuationRe visedReport_20131112.pdf

Johnson-Down, L., and Egeland, G.M. 2010. Adequate nutrient intakes are associated with traditional food consumption in Nunavut Inuit children aged 3-5 years. The Journal of Nutrition 140(7):1311-1316. https://doi.org/10.3945/jn.109.117887

Kenny, T.-A., and Chan, H.M. 2017. Estimating wildlife harvest based on reported consumption by Inuit in the Canadian Arctic. Arctic 70(1):1-12. https://doi.org/10.14430/arctic4625
Kenny, T.-A., Hu, X.F., Kuhnlein, H.V., Wesche, S.D., and Chan, H.M. 2018a. Dietary sources of energy and nutrients in the contemporary diet of Inuit adults: Results from the 2007-08 Inuit Health Survey. Public Health Nutrition 21(7):1319-1331. https://doi.org/10.1017/S1368980017003810

Kenny, T.-A., Fillion, M., Simpkin, S., Wesche, S.D., and Chan, H.M. 2018b. Caribou (Rangifer tarandus) and Inuit nutrition security in Canada. EcoHealth 15:590-607. https://doi.org/10.1007/s10393-018-1348-z

Kenny, T.-A., Fillion, M., MacLean, J., Wesche, S.D., and Chan, H.M. 2018c. Calories are cheap, nutrients are expensive - The challenge of healthy living in Arctic communities. Food Policy $80: 39-54$. https://doi.org/10.1016/j.foodpol.2018.08.006

Kosoy, N., and Corbera, E. 2010. Payments for ecosystem services as commodity fetishism. Ecological Economics 69(6):1228- 1236. https://doi.org/10.1016/j.ecolecon.2009.11.002

Kruse, J. 2011. Developing an Arctic subsistence observation system. Polar Geography 34(1-2):9-35. https://doi.org/10.1080/1088937X.2011.584448

Kuhnlein, H.V., and Humphries, M.M. 2017. Traditional animal foods of Indigenous peoples of northern North America: Montreal, Québec: Centre for Indigenous Peoples' Nutrition and Environment, McGill University. http://traditionalanimalfoods.org/

Kuhnlein, H.V., and Receveur, O. 1996. Dietary change and traditional food systems of Indigenous peoples. Annual Review of Nutrition 16: 417-442. https://doi.org/10.1146/annurev.nu.16.070196.002221

___ 2007. Local cultural animal food contributes high levels of nutrients for Arctic Canadian Indigenous adults and children. The Journal of Nutrition 137(4):1110-1114.

https://doi.org/10.1093/jn/137.4.1110

Kuhnlein, H.V., Receveur, O., Soueida, R., and Egeland, G.M. 2004. Arctic Indigenous peoples experience the nutrition transition with changing dietary patterns and obesity. The Journal of Nutrition 134(6):1447-1453. https://doi.org/10.1093/jn/134.6.1447

Kuhnlein, H.V., Erasmus, B., and Spigelski, D. 2009. Indigenous peoples' food systems: The many dimensions of culture, diversity and environment for nutrition and health. Rome: Food and Agriculture Organization of the United Nations. http://www.fao.org/3/i0370e/i0370e00.htm

Kuokkanen, R. 2011. Indigenous economies, theories of subsistence, and women: Exploring the social economy model for Indigenous governance. The American Indian Quarterly 35(2):215-240. https://doi.org/10.5250/amerindiquar.35.2.0215

Lambden, J., Receveur, O., and Kuhnlein, H.V. 2007. Traditional food attributes must be included in studies of food security in the Canadian Arctic. International Journal of Circumpolar Health 66(4):308-319. https://doi.org/10.3402/ijch.v66i4.18272 
Lecaudey, L.A., Schliewen, U.K., Osinov, A.G., Taylor, E.B., Bernatchez, L., and Weiss, S.J. 2018. Inferring phylogenetic structure, hybridization and divergence times within Salmoninae (Teleostei: Salmonidae) using RAD-sequencing. Molecular Phylogenetics and Evolution 124:82-99. https://doi.org/10.1016/j.ympev.2018.02.022

Lee, A., Mhurchu, C.N., Sacks, G., Swinburn, B., Snowdon, W., Vandevijvere, S., Hawkes, C., et al. 2013. Monitoring the price and affordability of foods and diets globally. Obesity Reviews 14(S1):82-95. https://doi.org/10.1111/obr.12078

Lysenko, D., and Schott, S. 2019. Food security and wildlife management in Nunavut. Ecological Economics 156:360 - 374. https://doi.org/10.1016/j.ecolecon.2018.10.008

Magdanz, J.S., Braem, N.S., Robbins, B.C., and Koster, D.S. 2010. Subsistence harvests in Northwest Alaska, Kivalina and Noatak, 2007. Technical Paper No. 354. Kotzebue: Alaska Department of Fish and Game Division of Subsistence. http://www.adfg.alaska.gov/techpap/tp354.pdf

Minich, K., Saudny, H., Lennie, C., Wood, M., WilliamsonBathory, L., Cao, Z., and Egeland, G.M. 2011. Inuit housing and homelessness: Results from the International Polar Year Inuit Health Survey 2007-2008. International Journal of Circumpolar Health 70(5):520-531. https://doi.org/10.3402/ijch.v70i5.17858

NAICS (North American Industry Classification System). 2017. NAICS manual. https://www.census.gov/naics/reference_files_tools/2017 NAICS_Manual.pdf

Natcher, D.C. 2009. Subsistence and the social economy of Canada's Aboriginal North. Northern Review 30:83-98.

Nunavut Food Security Coalition. 2014. Nunavut food security strategy and action plan 2014-16. Iqaluit: Nunavut Tunngavik Incorporated.

ht t p s://w w w.tunngavik.com/files/2014/0 5/ NunavutFoodSecurity Strategy_ENGLISH.pdf

Nutrition North Canada. 2018. Cost of the Revised Northern Food Basket in 2016-2017.

https://www.nutritionnorthcanada.gc.ca/eng/1519997966920/1 519998026166

Nyakatura, K., and Bininda-Emonds, O.R.P. 2012. Updating the evolutionary history of Carnivora (Mammalia): A new specieslevel supertree complete with divergence time estimates. BMC Biology 10: Article 12. https://doi.org/10.1186/1741-7007-10-12

O'Garra, T. 2017. Economic value of ecosystem services, minerals and oil in a melting Arctic: A preliminary assessment. Ecosystem Services 24:180-186. https://doi.org/10.1016/j.ecoser.2017.02.024

Pal, S., Haman, F., and Robidoux, M.A. 2013. The costs of local food procurement in two northern Indigenous communities in Canada. Food and Foodways 21(2):132-152. https://doi.org/10.1080/07409710.2013.792193

Priest, H., and Usher, P.J. 2004. The Nunavut wildlife harvest study: Final report. Iqaluit: Nunavut Wildlife Management Board.
Prowse, T.D., Furgal, C., Chouinard, R., Melling, H., Milburn, D., and Smith, S.L. 2009. Implications of climate change for economic development in northern Canada: Energy, resource, and transportation sectors. AMBIO: A Journal of the Human Environment 38(5):272-281.

https://doi.org/10.1579/0044-7447-38.5.272

Prum, R.O., Berv, J.S., Dornburg, A., Field, D.J., Townsend, J.P, Lemmon, E.M., and Lemmon, A.R. 2015. A comprehensive phylogeny of birds (Aves) using targeted next-generation DNA sequencing. Nature 526:569-573.

https://doi.org/10.1038/nature15697

Quintal-Marineau, M. 2017. 'Feeding our families; that's what we have been doing for centuries' Inuit women's sharing practices and strategies. Hunter Gatherer Research 3(4):583 - 599.

https://doi.org/10.3828/hgr.2017.30

Ready, E. 2017. Why subsistence matters. Hunter Gatherer Research 3(4):635-649.

https://doi.org/10.3828/hgr.2017.32

Ready, E., and Power, E.A. 2018. Why wage earners hunt: Food sharing, social structure, and influence in an Arctic mixed economy. Current Anthropology 59(1):74-97.

https://doi.org/10.1086/696018

Receveur, O., Boulay, M., and Kuhnlein, H.V. 1997. Decreasing traditional food use affects diet quality for adult Dene/Métis in 16 communities of the Canadian Northwest Territories. The Journal of Nutrition 127(11):2179-2186.

https://doi.org/10.1093/jn/127.11.2179

Redwood, D.G., Day, G.M., Beans, J.A., Hiratsuka, V.Y., Nash, S.H., Howard, B.V., Umans, J.G., and Koller, K.R. 2019. Alaska Native traditional food and harvesting activity patterns over 10 years of follow-up. Current Developments in Nutrition 3(11: nzz114. https://doi.org/10.1093/cdn/nzz114

The Revised Northern Food Basket. 2007. Minister of Indian Affairs and Northern Development.

Rodon, T., and Lévesque, F. 2015. Understanding the social and economic impacts of mining development in Inuit communities: Experiences with past and present mines in Inuit Nunangat. Northern Review 41:13-39. https://doi.org/10.22584/nr41.2015.002

Rosol, R., Powell-Hellyer, S., and Chan, H.M. 2016. Impacts of decline harvest of country food on nutrient intake among Inuit in Arctic Canada: Impact of climate change and possible adaptation plan. International Journal of Circumpolar Health 75(1): 31127.

https://doi.org/10.3402/ijch.v75.31127

Ruiz-Castell, M., Muckle, G., Dewailly, É., Jacobson, J.L., Jacobson, S.W., Ayotte, P., and Riva, M. 2015. Household crowding and food insecurity among Inuit families with school-aged children in the Canadian Arctic. American Journal of Public Health 105(3):e122 - e132. https://doi.org/10.2105/AJPH.2014.302290 
Schröter, M., van der Zanden, E.H., van Oudenhoven, A.P.E., Remme, R.P., Serna-Chavez, H.M., de Groot, R.S., and Opdam, P. 2014. Ecosystem services as a contested concept: A synthesis of critique and counter-arguments. Conservation Letters 7(6):514-523. https://doi.org/10.1111/conl.12091

Searles, E. 2016. To sell or not to sell: Country food markets and Inuit identity in Nunavut. Food and Foodways 24(34):194-212. https://doi.org/10.1080/07409710.2016.1210899

Sheehy, T., Roache, C., and Sharma, S. 2013. Eating habits of a population undergoing a rapid dietary transition: Portion sizes of traditional and non-traditional foods and beverages consumed by Inuit adults in Nunavut, Canada. Nutrition Journal 12: 70. https://doi.org/10.1186/1475-2891-12-70

Statistics Canada. 2017. Focus on Geography Series, 2016 census. Ottawa, Ontario: Statistics Canada.

https://www12.statcan.gc.ca/census-recensement/2016/as-sa/ fogs-spg/Index-eng.cfm

St-Germain, A.A.F., Galloway, T., and Tarasuk, V. 2019. Food insecurity in Nunavut following the introduction of Nutrition North Canada. CMAJ 191(20):E552-E558. https://doi.org/10.1503/cmaj.181617

Sustainable Development Working Group. 2019. The Arctic as a food-producing region. Tromsø, Norway: Arctic Council. https://sdwg.org/what-we-do/projects/the-arctic-as-a-foodproducing-region/

Titus, K., Haynes, T.L., and Paragi, T.F. 2009. The importance of moose, caribou, deer and small game in the diet of Alaskans. In: Watson, R.T., Fuller, M., Pokras, M., and Hunt, W.G., eds. Ingestion of lead from spent ammunition: Implications for wildlife and humans. Boise, Idaho: The Peregrine Fund. $137-143$.

https://doi.org/10.4080/ilsa.2009.0312
Usher, P.J. 1971. The Bankslanders: Economy and ecology of a frontier trapping community, Vol. 2: Economy and ecology. Ottawa: Northern Science Research Group, Department of Indian Affairs and Northern Development.

Wakegijig, J., Osborne, G., Statham, S., and Issaluk, M.D. 2013. Collaborating toward improving food security in Nunavut. International Journal of Circumpolar Health 72(1): 21201. https://doi.org/10.3402/ijch.v72i0.21201

Wenzel, G.W. 1991. Animal rights, human rights: Ecology, economy and ideology in the Canadian Arctic. Toronto, Ontario: University of Toronto Press. https://doi.org/10.3138/9781442670877

__ 2 2000. Sharing, money, and modern Inuit subsistence: Obligation and reciprocity at Clyde River, Nunavut. Senri Ethnological Studies 53:61-85.

___ 2009. Canadian Inuit subsistence and ecological instability - if the climate changes, must the Inuit? Polar Research 28(1):89-99. https://doi.org/10.1111/j.1751-8369.2009.00098.x

___ 2016. To have and have not; or, has subsistence become an anachronism? In: Codding, B.F., and Kramer, K.L., eds. Why forage?: Hunters and gatherers in the twenty-first century. Albuquerque: University of New Mexico Press. 43-60.

__ 2017. Canadian Inuit subsistence: Antinomies of the mixed economy. Hunter Gatherer Research 3(4):567-581. https://doi.org/10.3828/hgr.2017.29

Wenzel, G.W., Dolan, J., and Brown, C. 2016. Wild resources, harvest data and food security in Nunavut's Qikiqtaaluk region: A diachronic analysis. Arctic 69(2):147-159. https://doi.org/10.14430/arctic4562 